\title{
Amyloid and tau in the brain in sporadic Alzheimer's disease: defining the chicken and the egg
}

\author{
Cheryl A. Hawkes $\cdot$ Roxana O. Carare $\cdot$ Roy O. Weller
}

Received: 30 December 2013 / Accepted: 1 January 2014 / Published online: 23 January 2014

(C) The Author(s) 2014. This article is published with open access at Springerlink.com

In the October 2013 issue of Acta Neuropathologica there were three very interesting articles on: Amyloid or tau: the chicken or the egg? In the first article, David Mann and John Hardy [10] argued that the deposition of aggregated amyloid $\beta(\mathrm{A} \beta)$ protein in the brain is a primary driving force behind the pathogenesis of Alzheimer's disease with tau pathology following as a consequential or at least a secondary event. In the communication that followed, Braak and Del Tredici [3] presented the contrary argument with accumulation of tau protein as the primary event in sporadic Alzheimer's disease. Attems and Jellinger [2] questioned the concept of a chicken and egg and suggested that the majority of cases of age-associated dementia are not caused by one single primary pathological mechanism.

Many of the arguments put forward in these three contributions rely on observations derived from human brain material. Although human brain specimens have been essential for defining the diagnosis of Alzheimer's disease and other dementias and for identifying some of the problems associated with those dementias, the study of human material is not necessarily the best and sole way of solving the "chicken and egg" problem. It is tacitly assumed that the primary problems lie with the deposition of insoluble $A \beta$ as plaques in the brain, or the toxicity of soluble $A \beta$, or with the accumulation of hyperphosphorylated tau in neurons and neurites. But, have we identified the egg? What is the primary problem? In order to answer this question we should perhaps review the changes that occur in the brain with age and how they affect the pathophysiology of the brain and result in dementia.

C. A. Hawkes $\cdot$ R. O. Carare $(\bowtie) \cdot$ R. O. Weller Faculty of Medicine, Institute for Life Sciences, University of Southampton, Southampton, UK

e-mail: R.O.Carare@soton.ac.uk

R. O. Weller

e-mail: row@soton.ac.uk
One example of this approach would be to consider the major risk factors for sporadic Alzheimer's disease viz: age and possession of the $\varepsilon 4$ allele of apolipoprotein $\mathrm{E}$ (APOE4), and take the lead from observations in human brains to ask the questions "Why does $A \beta$ accumulate in the brain with age?" "What are the pathophysiological consequences for the brain of the accumulation of $\mathrm{A} \beta$ in the walls of cerebral arteries and in brain parenchyma?" It is clear from the study of human brains that there is an age-related failure of elimination of $\mathrm{A} \beta$. Experimental studies and observations in human brains suggest that various pathways for the elimination of $\mathrm{A} \beta$ from the brain fail with age. Those pathways include degradation by neprilysin [11] and other enzymes and absorption of $\mathrm{A} \beta$ into the blood $[13,19]$. In addition, there is an age-related failure of elimination of $\mathrm{A} \beta$ along the perivascular drainage pathways [7] that serve as lymphatic drainage pathways for interstitial fluid and solutes (including $A \beta$ ) from the brain $[4,5,17]$. Impaired elimination of $A \beta$ along perivascular drainage pathways is further accentuated in the presence of APOE4 [8]. Hallmarks of such failure are the deposition of $\mathrm{A} \beta$ aggregates in the walls of arteries as cerebral amyloid angiopathy (CAA) and as plaques of $\mathrm{A} \beta$ in the brain parenchyma; there is also a rise in the level of soluble $A \beta$ in the brain in Alzheimer's disease [9, 15] and the accumulation of fluid in subcortical white matter as leukoaraiosis [12]. The significance of CAA has been emphasised in human and experimental studies which showed that severe CAA was strongly related to the presence of dementia [6, 18].

Two major causes of age-related failure of perivascular elimination of $A \beta$ from the brain have been identified, first: the progressive stiffening that occurs in the walls of cerebral arteries with age [16]; second: the changes that occur in basement membranes with age [7]. Theoretical models suggest that the contrary wave that follows the pulse wave along cerebral arteries is a major motive force for perivascular 
drainage of $A \beta$ from the brain [14]. According to this model, stiffening of cerebral arteries would reduce the amplitude of pulsations and thus reduce the motive force for drainage of $A \beta$. This is supported by experimental studies showing that a reduction in arterial pulsations impedes perivascular drainage [1]. Age-related changes in vascular basement membranes that are the pathways for perivascular drainage and in their component proteins have been detected in human cerebral arteries (see [7]); in mice such changes are associated with demonstrably impaired perivascular drainage [7]. Impairment and slowing of perivascular drainage is associated with the formation of fibrillar amyloid in the walls of cerebral vessels as CAA which further impedes perivascular drainage of $A \beta$ [7]. Stiffening of cerebral artery walls and age-related changes in basement membranes appear to be universal factors in the failure of perivascular elimination of $\mathrm{A} \beta$ from the ageing brain and in Alzheimer's disease.

What, therefore, is the egg? Age-changes in the walls of cerebral arteries that impair the drainage of soluble $A \beta$ could well be a prime candidate [7]. The chicken that develops from this egg may be the accumulation of insoluble aggregates of $\mathrm{A} \beta$ as $\mathrm{CAA}$ and as plaques in the brain but it could also be loss of homoeostasis of the neuronal environment due to failure of elimination of a range of soluble metabolites from the brain parenchyma.

We have emphasised here that, despite the importance of studying the distribution of $A \beta$ and tau in human post-mortem brain in dementias such as Alzheimer's disease, it is equally important to consider the wider pathophysiological effects of ageing of cerebral arteries on the brain in relation to Alzheimer's disease. Such changes may lead not only to the accumulation of $A \beta$ in the brain and artery walls but also to loss of homoeostasis of the neuronal environment and disturbance of neuronal function that may be related to dementia. Facilitation of elimination of soluble $A \beta$ and other metabolites from the brain along the walls of ageing arteries could be a fruitful therapeutic strategy for the prevention and management of Alzheimer's disease [5].

Acknowledgments The work discussed here is derived from projects funded by the Biotechnology and Biological Sciences Research Council UK and by Alzheimer's Research UK.

Open Access This article is distributed under the terms of the Creative Commons Attribution License which permits any use, distribution, and reproduction in any medium, provided the original author(s) and the source are credited.

\section{References}

1. Arbel-Ornath M, Hudry E, Eikermann-Haerter K, Hou S, Gregory JL, Zhao L, Betensky RA, Frosch MP, Greenberg SM, Bacskai BJ (2013) Interstitial fluid drainage is impaired in ischemic stroke and Alzheimer's disease mouse models. Acta Neuropathol 126(3):353-364. doi:10.1007/s00401-013-1145-2
2. Attems J, Jellinger KA (2013) Amyloid and tau: neither chicken nor egg but two partners in crime! Acta Neuropathol 126(4):619621. doi:10.1007/s00401-013-1167-9

3. Braak H, Del Tredici K (2013) Reply: the early pathological process in sporadic Alzheimer's disease. Acta Neuropathol 126(4):615-618. doi:10.1007/s00401-013-1170-1

4. Carare RO, Bernardes-Silva M, Newman TA, Page AM, Nicoll JAR, Perry VH, Weller RO (2008) Solutes, but not cells, drain from the brain parenchyma along basement membranes of capillaries and arteries. Significance for cerebral amyloid angiopathy and neuroimmunology. Neuropathol Appl Neurobiol 34:131-144

5. Carare RO, Hawkes CA, Jeffrey M, Kalaria RN, Weller RO (2013) Review: cerebral amyloid angiopathy, prion angiopathy, CADASIL and the spectrum of protein elimination failure angiopathies (PEFA) in neurodegenerative disease with a focus on therapy. Neuropathol Appl Neurobiol 39(6):593-611. doi:10.1111/nan.12042

6. CFAS NGoM (2001) Pathological correlates of late-onset dementia in a multicentre, community-based population in England and Wales. Lancet 357:169-175

7. Hawkes CA, Hartig W, Kacza J, Schliebs R, Weller RO, Nicoll JA, Carare RO (2011) Perivascular drainage of solutes is impaired in the ageing mouse brain and in the presence of cerebral amyloid angiopathy. Acta Neuropathol 121:431-443. doi:10.1007/ s00401-011-0801-7

8. Hawkes CA, Sullivan PM, Hands S, Weller RO, Nicoll JA, Carare RO (2012) Disruption of arterial perivascular drainage of amyloidbeta from the brains of mice expressing the human APOE epsilon4 allele. PLoS ONE 7(7):e41636. doi:10.1371/journal.pone.0041636

9. Lue LF, Kuo YM, Roher AE, Brachova L, Shen Y, Sue L, Beach T, Kurth JH, Rydel RE, Rogers J (1999) Soluble amyloid beta peptide concentration as a predictor of synaptic change in Alzheimer's disease. Am J Pathol 155(3):853-862

10. Mann DM, Hardy J (2013) Amyloid or tau: the chicken or the egg? Acta Neuropathol 126(4):609-613. doi:10.1007/s00401-013-1162-1

11. Miners JS, Van Helmond Z, Chalmers K, Wilcock G, Love S, Kehoe PG (2006) Decreased expression and activity of neprilysin in Alzheimer disease are associated with cerebral amyloid angiopathy. J Neuropathol Exp Neurol 65:1012-1021

12. Roher AE, Kuo Y-M, Esh C, Knebel C, Weiss N, Kalback W, Luehrs DC, Childress JL, Beach TG, Weller RO, Kokjohn TA (2003) Cortical and leptomeningeal cerebrovascular amyloid and white matter pathology in Alzheimer's disease. Mol Med 9:112-122

13. Sagare AP, Bell RD, Zlokovic BV (2012) Neurovascular dysfunction and faulty amyloid beta-peptide clearance in Alzheimer disease. Cold Spring Harbor Perspect Med 2(10). doi:10.1101/cshperspect.a011452

14. Schley D, Carare-Nnadi R, Please CP, Perry VH, Weller RO (2006) Mechanisms to explain the reverse perivascular transport of solutes out of the brain. J Theor Biol 238:962-974

15. van Helmond Z, Miners JS, Kehoe PG, Love S (2010) Oligomeric Abeta in Alzheimer's disease: relationship to plaque and tangle pathology, APOE genotype and cerebral amyloid angiopathy. Brain Pathol 20(2):468-480. doi:10.1111/j.1750-3639.2009.00321.x

16. Weller RO, Boche D, Nicoll JA (2009) Microvasculature changes and cerebral amyloid angiopathy in Alzheimer's disease and their potential impact on therapy. Acta Neuropathol 118:87-102

17. Weller RO, Djuanda E, Yow HY, Carare RO (2009) Lymphatic drainage of the brain and the pathophysiology of neurological disease. Acta Neuropathol 117:1-14

18. Xu W, Xu F, Anderson ME, Kotarba AE, Davis J, Robinson JK, Van Nostrand WE (2014) Cerebral microvascular rather than parenchymal amyloid-beta protein pathology promotes early cognitive impairment in transgenic mice. J Alzheimer's Disease 38(3):621-632. doi:10.3233/JAD-130758

19. Zlokovic BV (2004) Clearing amyloid through the blood-brain barrier. J Neurochem 89:807-811 